\title{
NEW RECORDS OF ALIEN PLANTS - LUDWIGIA PEPLOIDES (KUNTH) P. H. RAVEN, REYNOUTRIA SACHALINENSIS (F. SCHMIDT) NAKAI AND NICOTIANA GLAUCA GRAHAM IN CROATIA
}

\author{
Nina Vuković", Vedran Šegota ${ }^{1}$, Anja Rimac ${ }^{2}$, \\ Nikola Koletić ${ }^{2} \&$ Antun Alegro ${ }^{2}$ \\ ${ }^{1} \mathrm{ZA}$ and ZAHO, Faculty of Science, University of Zagreb, \\ Marulićev trg 20/II, HR-10000, Zagreb, Croatia \\ ${ }^{2}$ Division of Botany, Department of Biology, Faculty of Science, \\ University of Zagreb, Marulićev trg 20/II, HR-10000, Zagreb, Croatia
}

Vuković, N., Šegota, V., Rimac, A., Koletić, N. \& Alegro, A.: New records of alien plants - Ludwigia peploides (Kunth) P. H. Raven, Reynoutria sachalinensis (F. Schmidt) Nakai and Nicotiana glauca Graham in Croatia. Nat. Croat., Vol. 30, No. 1, 27-35, 2021, Zagreb.

Invasive alien species Ludwigia peploides, Reynoutria sachalinensis and Nicotiana glauca, currently registered in Croatia with small number of records, were found during fieldwork undertaken mostly through the national monitoring of waters from 2018 to 2020. Ludwigia peploides was previously recorded only once in the River Ilova, the existing data for $R$. sachalinensis indicate only three confirmed findings, in Čabar, Karlovac and Donja Stubica, while the previous data for N. glauca include several localities in Central and Southern Dalmatia. The new records are as follows: two findings of $L$. peploides refer to the River Česma (Obedišće and Sišćani); three records of $R$. sachalinensis refer to Gorski Kotar (Gerovo and Čabar), while N. glauca is newly recorded in the Neretva River Valley (Krvavac) and the island of Krk. Despite their potential invasiveness, all three are still locally naturalized and currently their spread is very slow and limited in Croatia.

Keywords: Invasive species, new records, distribution

Vuković, N., Šegota, V., Rimac, A., Koletić, N. \& Alegro, A.: Novi nalazi stranih vrsta - Ludwigia peploides (Kunth) P. H. Raven, Reynoutria sachalinensis (F. Schmidt) Nakai i Nicotiana glauca Graham u Hrvatskoj. Nat. Croat., Vol. 30, No. 1, 27-35, 2021, Zagreb.

Invazivne strane vrste Ludwigia peploides, Reynoutria sachalinensis i Nicotiana glauca, trenutno zabilježene u Hrvatskoj s malim brojem nalaza, nađene su tijekom terenskih istraživanja obavljanih većinom u sklopu nacionalnog monitoringa voda u razdoblju 2018.-2020. Ludwigia peploides je dosad bila zabilježena samo jednom, u rijeci Ilovi, postojeći podaci za $R$. sachalinensis ukazuju na samo tri potvrđena nalaza, u Cabru, Karlovcu i Donjoj Stubici, a postojeći podaci za N. glauca odnose se na nekoliko lokaliteta u srednjoj i južnoj Dalmaciji. Novi nalazi su sljedeći: dva nalaza L. peploides za rijeku Česmu (Obedišće i Sišćani); tri nalaza R. sachalinensis za Gorski kotar (Gerovo i Čabar), a N. glauca je novozabilježena za dolinu rijeke Neretve (Krvavac) i otok Krk. Usprkos potencijalnoj invazivnosti, sve tri vrste su zasad tek lokalno naturalizirane i trenutno je njihovo širenje u Hrvatskoj vrlo sporo i ograničeno.

Ključne riječi: invazivne vrste, novi nalazi, rasprostranjenost

\footnotetext{
* Corresponding author: nina.vukovic@biol.pmf.hr
} 


\section{INTRODUCTION}

The spread of invasive alien species (IAS) is globally a large problem in nature conservation; IAS are even recognized as the second major cause of biodiversity loss (Genovesi \& Shine, 2011). Apart from threatening local biodiversity, IAS represent a serious problem to economies and human health worldwide. Invasive weeds, pests or pathogens often cause significant yield losses (PAINI et al., 2016), while some IAS may cause health issues such as allergies or skin irritations (e.g. RASMUSSEN et al., 2017; Hashimoto \& Yokozeki, 2019; Schaffner et al., 2020). In the attempt to reduce the numerous negative impacts of IAS, the European Union produced a regulation that tackles the most troublesome IAS in the EU territory (ANONYMOUS, 2014). This regulation applies to the list of species of Union concern, which is regularly updated and at the moment includes 66 species (ANONYMOUs, 2016; 2017; 2019).

Ludwigia peploides (Kunth) P. H. Raven (Onagraceae) is a creeping (semi)aquatic plant originating from the Americas and possibly Australia, frequently used as an ornamental and therefore deliberately introduced into other parts of the world (CABI, 2020). Its prolific vegetative growth together with reproduction from fragments and seeds make this plant a very successful colonizer. Ludwigia peploides is recognized as troublesome in the European Union, and has been listed as a species of European concern since 2016 (AnONymous, 2016). Its detrimental effects are best observable in France, where L. peploides was introduced in 1830 and subsequently became one of the most dangerous aquatic invasive plants, spreading rapidly and forming dense mats consequently blocking waterways and causing major biodiversity loss (CABI, 2020). The species was firstly recorded in Croatia in 2018, in the river Ilova (BUZJAK \& SEDLAR, 2018). This record has been so far the only reported locality in Croatia. There it was recorded in dense mats, occurring in many micro-localities scattered along a $2 \mathrm{~km}$ of the river course.

Reynoutria sachalinensis (F. Schmidt) Nakai (Polygonaceae) is a large, perennial herb originating from Southeast Asia, introduced elsewhere as an ornamental plant (Bailey \& Conolly, 2000). Like its relative R. japonica Houtt. and their stabilized hybrid $R . \times$ bohemica Chrtek et Chrtková, the plant exhibits significant vegetative growth through branched underground woody rhizomes, and may spread via stem fragments and seeds. It mostly invades riparian habitats, outcompeting and displacing native vegetation. Although not as invasive as its congeners, $R$. sachalinensis provides pollen to male-sterile $R$. japonica resulting in the creation of $R . \times$ bohemica, and current data suggest that the hybrid is the most pernicious invader among the three. The first records of $R$. sachalinensis in Croatia were erroneous due to the confusion with $R . \times$ bohemica, while the revised data suggest that the species has been scattered in three geographically distinct localities: the river Čabranka near Čabar, Donja Stubica and Karlovac (Vuković et al., 2019). The populations in Stubica and Karlovac were rather small and localized, while the plants near Čabar were more numerous, growing between the road and the river Cabranka, covering approximately $200 \mathrm{~m}^{2}$. Reynoutria sachalinensis is currently not listed in the Union list, but is being considered for inclusion and a risk assessment is currently being carried out (BoRšić, pers. comm.)

Nicotiana glauca Graham (Solanaceae) is an evergreen, branched perennial of South-American origin, introduced into other parts of the world as a garden and landscape ornamental (CABI, 2020a). Unlike the previous two aliens, this species does not readily reproduce by vegetative means but can produce huge numbers of 
extremely small seeds, easily distributed by wind or water. It mostly occupies semi-natural, disturbed, warm and dry habitats, where it can form dense stands and outcompete native vegetation. The first Croatian record refers to the herbarium material collected in 1977 on the island of Lokrum in the southern Adriatic (BoGDANOvić et al., 2006). This record was, however, "lost" in the ZA collection until Bogdanović et al. (2006) found the species in 2002 on the island of Vis in Central Dalmatia, and subsequently searched the ZA collection for any historical data. In 2004, the same authors recorded other populations in Central and Southern Dalmatia (the island of Lokrum and cities of Split and Dubrovnik). The only subsequent record was the one from JeričEvić et al. (2014) who found N. glauca on the island of Korčula.

All three species are recognized as invasive in the Flora Croatica Database (NIKOLIĆ, 2005-onwards), while L. peploides and R. sachalinensis are also listed by EPPO, as recommended for regulation as quarantine pest (EPPO, 2019) and invasive alien plant (EPPO, 2020), respectively. Furthermore, L. peploides is listed on the list of species of Union concern (AnONymous, 2016).

\section{MATERIAL \& METHODS}

The fieldwork was undertaken in 2018, 2019 and 2020 mostly within the framework of a national inland waters monitoring scheme, carried out according to the Water Framework Directive (European Community, 2000). The scheme covers several hundred of freshwater localities monitored at intervals of 2-3 years, with 150-200 localities inspected yearly. These localities are scattered across the whole Croatia, while the inspection of the localities includes the assessment of the abundance and cover of macrophytes. However, due to the large number of localities studied through many long-distance journeys over a large territory, other interesting plants apart from macrophytes are often recorded. The exception is Nicotiana glauca, which was found during a project of mapping invasive alien plants in the Neretva River Valley in 2019, and by sporadic visits to the island of Krk in 2020.

The coordinates of the localities were recorded using a Garmin eTrex 20× GPS device. The species were identified using the following literature: JACONO (2017), BOGDANOvić et al. (2006), and BAILEY \& Wisskirchen (2006) for L. peploides, N. glauca and R. sachalinensis, respectively. Several specimens of L. peploides were collected and herbarized, and deposited in ZA and ZAGR collections.

\section{RESULTS}

Ludwigia peploides was detected in two localities related to the river Česma (Tab.1, Appendix 1). At the first locality (Obedišće) the alien was first spotted at the confluence of a side-channel into the river. The river was subsequently inspected $100 \mathrm{~m}$ downstream of the confluence, and other infestations were found, although rather small, the largest covering approximately $1 \mathrm{~m}^{2}$. The plants were recorded in the stage of early growth, with only floating leaves developed on the water surface and no emergent stems or flowers.

The other site was at Sišćani fishponds, where a channel encompassing the western border of the fishpond connects to the river. Here, a large population of fully developed, flowering plants was found in the channel, while the banks of the channel 
were fully overgrown (Fig. 1). The plants were vigorous, with floating leaves stretching into the channel and emergent stems occupying its banks, producing flowers and fruits (Fig. 1). Similarly, the river Česma was inspected near the confluence of the channel and other populations were found. So far, the infestations of the river were very small and patchy, recorded in the stage of early growth, with no emergent stems (Fig. 1).
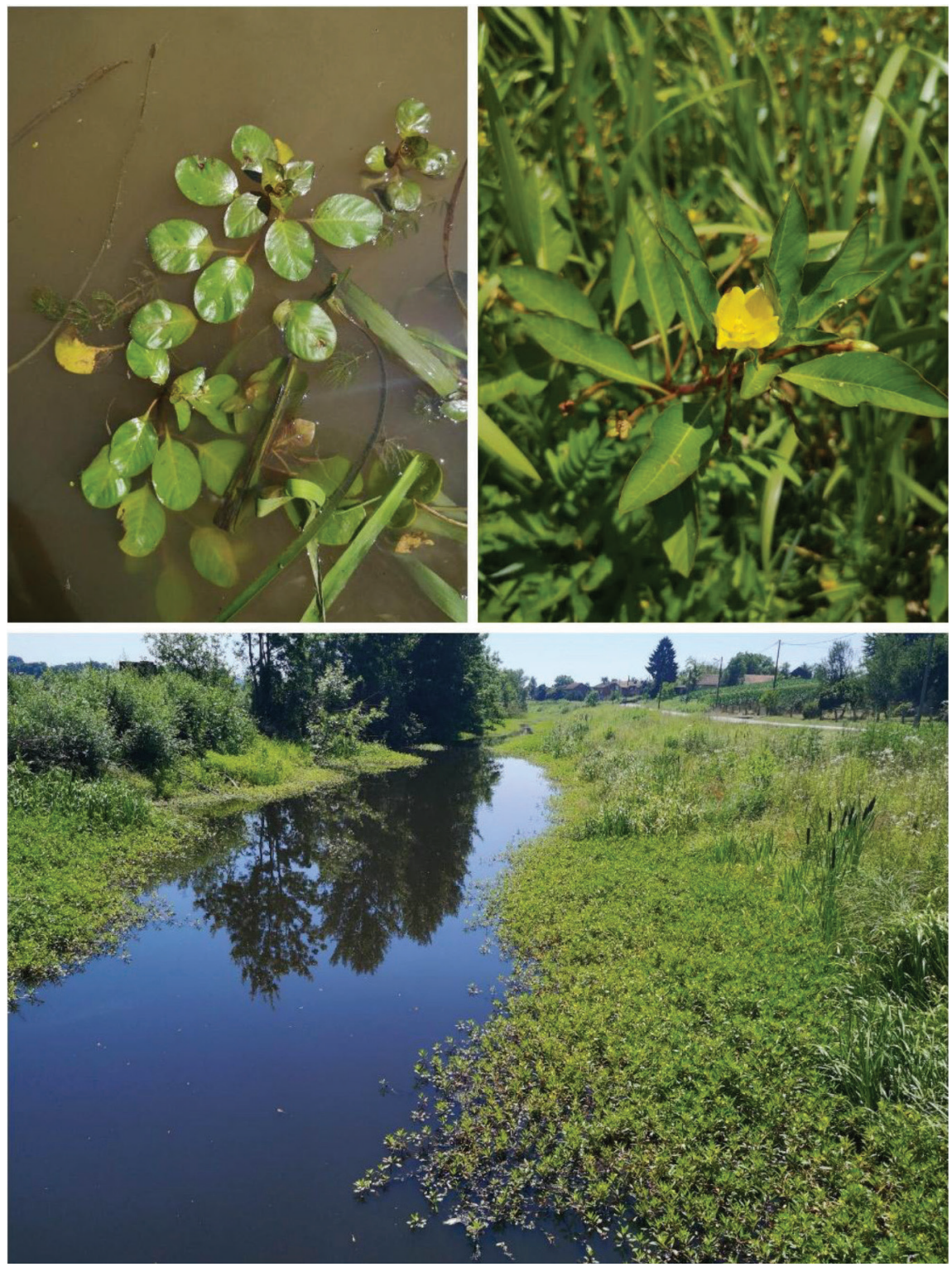

Fig. 1. Ludwigia peploides. Floating shoots in the stage of early growth in Obedišće (above, left), emergent, flowering shoots in Sišćani (above, right), large population of Ludwigia peploides invading a channel in Sišćani (below). 
Three new populations of Reynoutria sachalinensis were recorded in Gorski Kotar, one in the settlement of Čabar, and two in the settlement of Gerovo (Tab. 1, Appendix 1). The population in Čabar was recorded on the right bank of the river Cabranka (Fig. 2), $2 \mathrm{~km}$ upstream from the previous literature record. Here, young shoots were observed emerging from the recently mowed area along the river (Fig. 2). Populations in Gerovo can be described as follows: 1) an approximately $50 \times 10 \mathrm{~m}$ large stand stretching by the road, and 2) a few square meters next to an old house occupied by R. sachalinensis, on the left bank of the (channelized) river Gerovčica (Fig. 2).

Nicotiana glauca was found in two geographically distant areas on the eastern Adriatic coast: the Neretva River Valley (southern Dalmatia, southern Adriatic) and the island of Krk (Quarnero bay, northern Adriatic) (Tab. 1, Appendix 1). In the Neretva River Valley, two sites with $N$. glauca were recorded in the settlement Krvavac, both composed of only a few plants, flowering at the time (Fig. 3). The finding on Krk relates to a single flowering plant growing from a crevice of an old wall (Fig. 3).

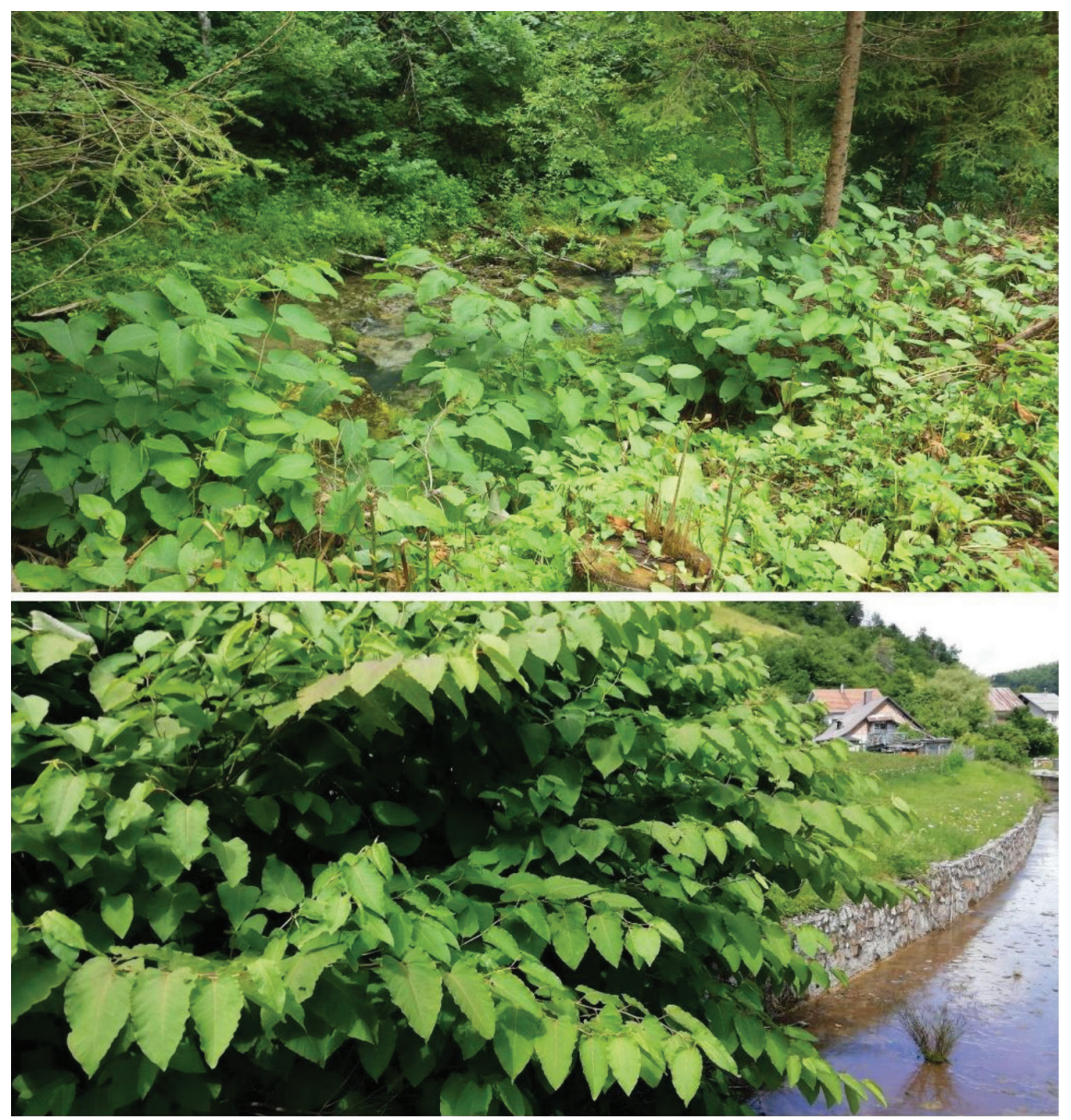

Fig. 2. Emerging shoots of Reynoutria sachalinensis along Čabranka in Čabar (above), a dense stand of $R$. sachalinensis along river Gerovčica in Gerovo (below). 

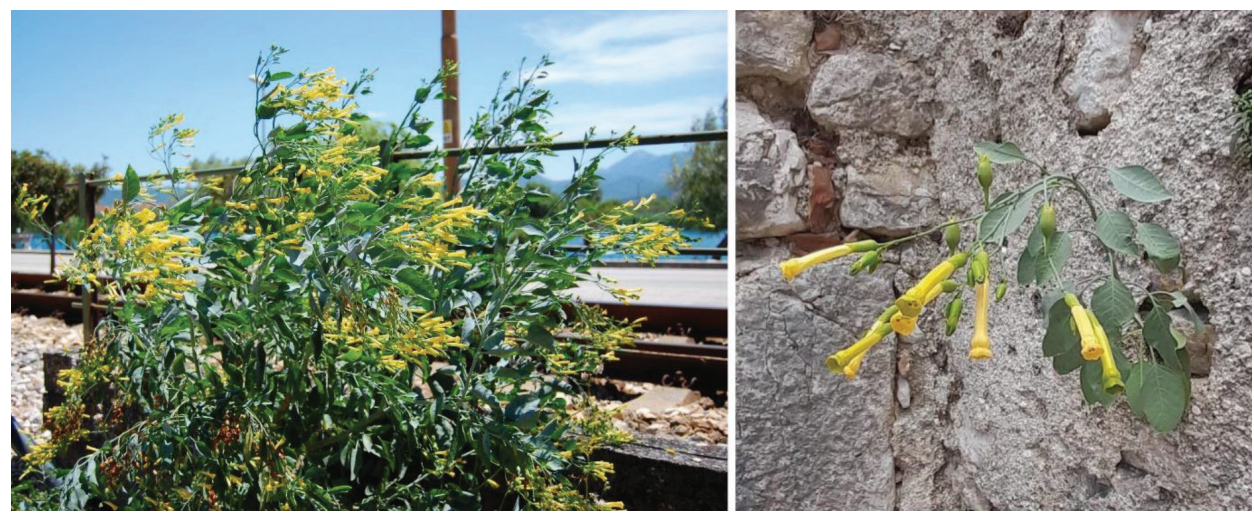

Fig. 3. Nicotiana glauca in Krvavac (left), and Krk (right).

Tab. 1. New records of Ludwigia peploides, Reynoutria sachalinensis and Nicotiana glauca in Croatia with GPS coordinates in WGS84 coordinate system.

\begin{tabular}{|l|c|c|l|c|}
\hline Species & WGS84 X & WGS84 Y & Locality & Date \\
\hline L. peploides & 16,558352 & 45,626532 & Obedišće (River Česma) & 10.07 .2020$. \\
\hline L. peploides & 16,640288 & 45,826632 & Sišćani (River Česma) & 10.07 .2020$. \\
\hline R. sachalinensis & 14,645000 & 45,597770 & Čabar & 29.06 .2018$. \\
\hline R. sachalinensis & 14,635590 & 45,516163 & Gerovo (River Gerovčica) & 17.07 .2020$. \\
\hline R. sachalinensis & 14,632072 & 45,506805 & Gerovo & 29.06 .2018$. \\
\hline N. glauca & 17,590302 & 43,026044 & Krvavac (Neretva River Valley) & 28.06 .2019$. \\
\hline N. glauca & 17,591168 & 43,027067 & Krvavac (Neretva River Valley) & 28.06 .2019$. \\
\hline N. glauca & 14,574530 & 45,027499 & Island Krk & 04.08 .2020$. \\
\hline
\end{tabular}

\section{DISCUSSION}

Once established and widespread, IAS are almost impossible to eradicate. For this reason, preventing new introductions and disabling further spread (early detection and rapid response) of newly established IAS is a priority aim of national strategies against biological invasions. New records of "rare" invasive plants should be taken as a serious alarm, and actions should be taken to prevent their massive distribution across large areas.

The newly found populations of Ludwigia peploides are located on the same river, which means they almost certainly originate from the same source. The absolute distance between these localities is $23 \mathrm{~km}$, and most probably other infestations exist in between. A previous record on the river Ilova (BUZJAK \& SEDLAR, 2018) is relatively close to the new localities (30 km from Obedišće and $40 \mathrm{~km}$ from Sišćani); however, these two watercourses are not connected so this population might originate from elsewhere or the plants might have been transferred through a vector (fishing equipment, boats, birds etc.). Most importantly, both rivers flow into the river Lonja, the core river of Lonjsko Polje Nature Park, a significant wetland area especially important for birds and internationally recognized as a Ramsar site (RAMSAR SITES INFORMATION Service, 2020). The finding of L. peploides in these particular localities and its 
potential spread into a valuable and protected area is obviously a serious problem. This is especially valid in view of the same Nature Park already having a significant problem with the invasion of Amorpha fruticosa L., a N American shrub that spreads quickly in regularly flooded areas. Eradication is perhaps still possible in Česma, where minor infestations in the early growth stage were mainly found. However, study of the whole course is necessary to reveal the extent of its current distribution, and monitoring of the downstream areas is recommended, to detect the possible spread towards other watercourses and tributaries as soon as possible. The same localities on the Česma were previously inspected in 2016 through the monitoring of inland waters, and L. peploides was not recorded, therefore most probably the arrival of the species is indeed very recent. On the other hand, the locality on Ilova was not inspected before 2018 .

According to the current data, Reynoutria sachalinensis does not display invasive behaviour in Croatia. A comprehensive field study of all three Reynoutria taxa in Croatia confirmed only three localities in the field (Vuković et al., 2019). This may mean that the spread of the species is rather slow, but it could also be that the arrival of the species was more recent than previously thought. Records previously confirmed in the field refer to 2016, while older literature records were identified either as erroneous, or could not be confirmed. Noteworthily, the oldest records from the 1970s were identified as erroneous based on the revision of the herbarium material (Vuković et al., 2019). One of the newly found localities is in the settlement of Čabar, approximately $2 \mathrm{~km}$ upstream from the previous literature record (Vuković et al., 2019). The other two populations in Gorski Kotar are in Gerovo, located $1 \mathrm{~km}$ apart and approximately $10 \mathrm{~km}$ south of Čabar. Most probably the populations of this area originate from the same source, possibly introduced from the neighbouring Slovenia, where the species has been confirmed since the late '80s (STRGulc KrajŠEK \& Jogan, 2011). Reynoutria taxa are frequently found growing along roads or watercourses (Vuković et al., 2019), which are often maintained through periodic mowing. Due to their capacity for vegetative spread via stem fragments, mowing might cause the dispersion of plants into new areas through stowaways on machinery or equipment.

Known records of Nicotiana glauca imply that its behaviour in Croatia is currently non-invasive. During a detailed, comprehensive mapping of a large area, only two small populations were found in the Neretva River Valley, probably originating from the same source. This record in southern Dalmatia fits into the previously registered extent of occurrence of this plant in Croatia (Bogdanović et al., 2006). More interestingly, the finding on Krk is geographically isolated, $200 \mathrm{~km}$ northwest of Split, currently the northernmost reported finding (Bogdanović et al., 2006). Given that the plant is used as an ornamental, the long-distance spread most probably occurs through sharing among gardeners, a common practice for obtaining garden plants in Croatia. Escapes from gardens occur through the prolific production of tiny seeds; although seemingly, no significant release to nature has been detected so far.

Although these alien species are seemingly not problematic in Croatia so far, monitoring of their populations is a reasonable measure to undertake. Prevention of introduction and spread before a species becomes a noxious weed is the best management practice for invasive species. It is true that the occurrences are still localized, with rather small populations, but control measures are advisable in the early stage of invasion (i.e. before the species are widespread) to prevent further spread. 


\section{ACKNOWLEDGMENTS}

The authors would like to thank the State Institution for Water Management "Hrvatske vode" and Public Institution for the Management of Protected Areas in Dubrovnik-Neretva County for the financial support of corresponding projects.

Received September 24, 2020

\section{REFERENCES}

Anonymous, 2014: Regulation (EU) No 1143/2014 of the European Parliament and of the Council on the prevention and management of the introduction and spread of invasive alien species. Official Journal of the European Union 317, 35-55.

Anonymous, 2016: Commission Implementing Regulation (EU) 2016/1141 adopting a list of invasive alien species of Union concern pursuant to Regulation (EU) No 1143/2014 of the European Parliament and of the Council. Official Journal of the European Union 189, 4-8.

Anonymous, 2017: Commission Implementing Regulation (EU) 2017/1263 updating the list of invasive alien species of Union concern established by Implementing Regulation (EU) 2016/1141 pursuant to Regulation (EU) No 1143/2014 of the European Parliament and of the Council. Official Journal of the European Union 182, 37-39.

Anonymous, 2019: Commission Implementing Regulation (EU) 2019/1262 amending Implementing Regulation (EU) 2016/1141 to update the list of invasive alien species of Union concern. Official Journal of the European Union 199, 1-4.

Bogdanović, S., Mitić B., Ruščić, M. \& Dolina, K., 2006: Nicotiana glauca Graham (Solanaceae), a new invasive plant in Croatia. Acta Botanica Croatica 65(2), 203-209.

Bailey, J. P. \& Conolly, A. P., 2000: Prize-winners to pariahs - A history of Japanese Knotweed s.l. (Polygonaceae) in the British Isles. Watsonia 23, 93-110.

Buzjak, S. \& Sedlar, Z., 2018: Ludwigia peploides (Kunth) P.H. Raven - floating water primrose, a new species in Croatian flora from the list of invasive alien species of Union concern. Natura Croatica 27(2), 351-356.

EPPO, 2019: EPPO Standards PM 1/2(28). A1 and A2 lists of pests recommended for regulation as quarantine pests.

EPPO, 2020: Fallopia sachalinensis. URL: https://gd.eppo.int/taxon/REYSA/categorization.

European Community, 2000: Directive 2000/60/EC of the European Parliament and of the Council of 23 October 2000 establishing a framework for Community action in the field of water policy. Official Journal of the European Communities L327: 1-72.

Genovesi, P. \& Shine, C., 2011: European Strategy on Invasive Alien Species. Convention on the Conservation of European Wildlife and Habitats (Bern Convention). Nature and environment, No. 161. Council of Europe Publishing, Strasbourg.

Наsнiмото, T. \& Yoкоzeкi, H., 2019: Occupational contact dermatitis caused by Eucalyptus species and Tanacetum parthenium. Contact Dermatitis 80(5), 333-334.

JACONO, C., 2017: Identification of common aquatic water-primrose species in Florida. University of Florida, Center for Aquatic \& Invasive Plants and The University of Florida Herbarium, Florida Museum Gainesville, Florida. Available at: https://plants.ifas.ufl.edu/site/assets/files/2615/ ludwigiaidguide.pdf

Jeričević, M., JeričEvić, N. \& Jasprica, N., 2014: Floristic novelties from the island of Korčula and peninsula of Pelješac (south Croatia). Natura Croatica 23(2), 241-253.

CABI, 2020: Ludwigia peploides [original text by Alison Mikulyuk] In: Invasive Species Compendium. Wallingford, UK. CAB International. URL: www.cabi.org/isc.

CABI, 2020a: Nicotiana glauca [original text by Isabel Jones]. In: Invasive Species Compendium. Wallingford, UK: CAB International. URL: www.cabi.org/isc.

Nikolić, T. (ed.), 2005-onwards: Flora Croatica Database. Faculty of Science, University of Zagreb. URL: http://hirc.botanic.hr/fcd.

Paini, D. R., Sheppard, A. W., Cook D. C., De Barro, P. J., Worner, S. P. \& Thomas, M. B., 2016: Global threat to agriculture from invasive species. PNAS 113(27), 7575-7579. 
Ramsar Sites Information Service, 2020: Lonjsko Polje Nature Park. URL: https://rsis.ramsar.org/ ris $/ 584$.

Rasmussen, K., Thyrring, J., Muscarella, L. \& Borchsenius, F., 2017: Climate-change-induced range shifts of three allergenic ragweeds (Ambrosia L.) in Europe and their potential impact on human health. PeerJ 5:e3104.

Schaffner, U., Steinbach, S., Sun, Y., Skjøth, C. A., de Weger, L. A., Lommen, S. T., Augustinus, B. A., Bonini, M., Karrer, G., Šikoparija, B., Thibaudon, M. \& Müller-Schärer, H., 2020: Biological weed control to relieve millions from Ambrosia allergies in Europe. Nature Communications 11(1), 1745.

Strgulc KrajŠEk, S. \& Jogan, N., 2011: The genus Fallopia Adans. in Slovenia. Hladnikia 28, 17-40.

Vurović, N., Šegota, V., Alegro, A., Koletić, N., Rimac, A. \& Dekanić, S., 2019: “Flying under the radar" - how misleading distributional data led to wrong appreciation of knotweeds invasion (Reynoutria spp.) in Croatia. BioInvasions Records 8(1), 175-189.

\section{APPENDIX 1.}

Distribution maps of Ludwigia peploides, Reynoutria sachalinensis and Nicotiana glauca with previously recorded localities (Old records) and localities newly found in this study (New records).

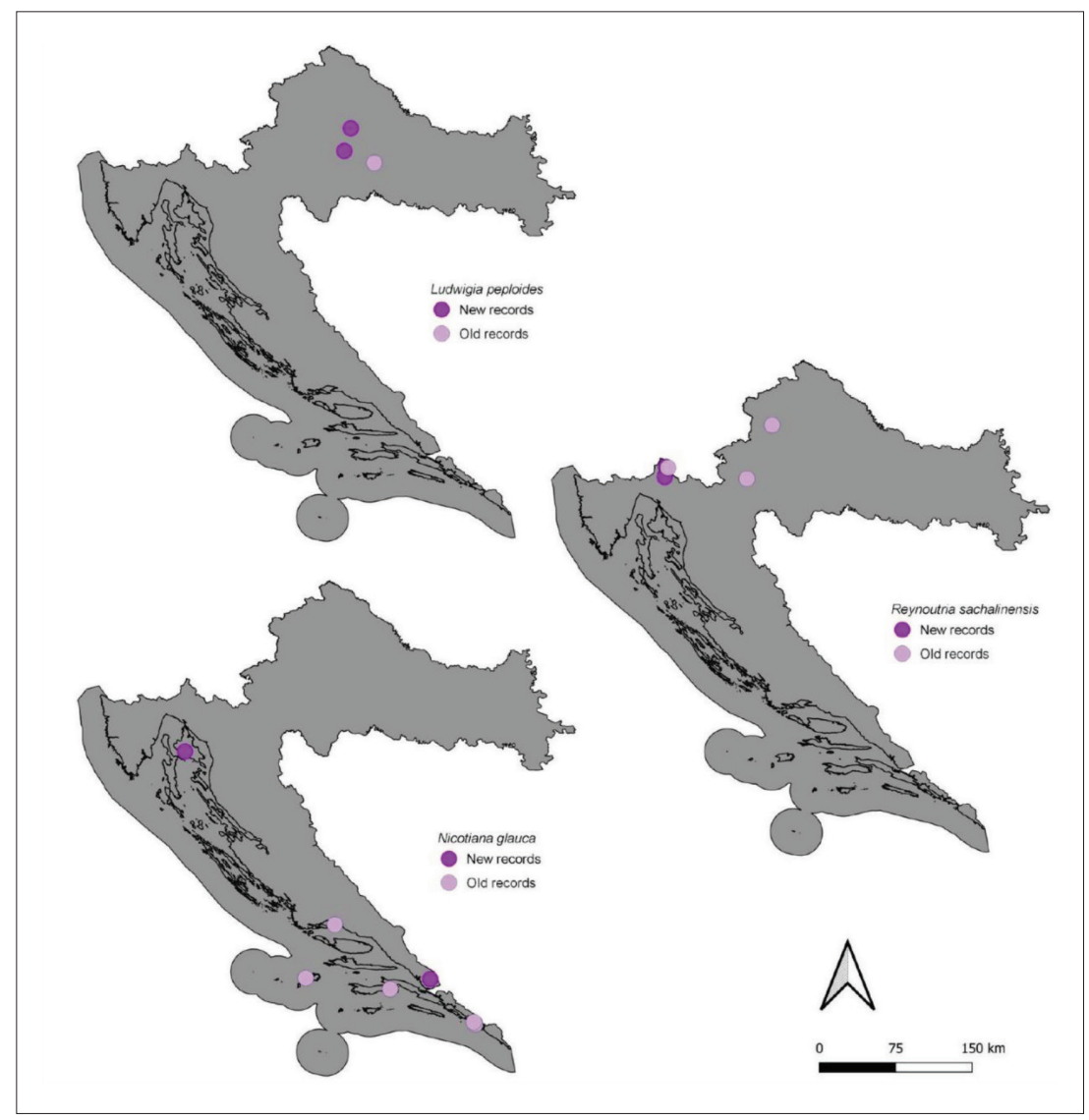

